\title{
Plant residue quality index and ecological potential approach for selective reincorporation of crop residues in soil.
}

Richa Rajput ${ }^{\mathrm{a}^{*},}$ Kusum Arunachalam ${ }^{\mathrm{a}}$

aSchool of Environment and Natural Resources, Doon University, Mothorowala Rd, Kedarpur, Uttarakhand 248001, India

*Corresponding author

\begin{abstract}
Reintegration of agricultural residue into the soil is a sustainable approach for replenishment of soil nutrients. Plant physiology determines the quality of residue produced by a crop and its quality governs the process of decomposition in the soil. The present study attempts to establish formulated approach to select quality crop residues for re-usage in soil. Four major crops, rice, wheat, maize and sugarcane were selected to analyse their quality and quantitative potential to generate a quality index. Residue production ratio (RPR), agricultural ecological potential (AEP) and, gross residue potential (GRP) values were determined to correlate their decomposition pattern with nutrient release rate. The calculated gross residue potential showed the availability of residue generated by crop was highest in wheat. Agricultural ecological potential further implied that $48 \%$ of wheat and maize crop residue should be left on the field for maintaining ecological services. The results are studied in coherence to explain the ecological importance of retaining crop residues in the field. The chemical parameters integrated as plant residue quality index (PRQI) further confirms the high nutrient value of wheat and rice crop residues correlated with their higher decomposition rate. The present study implies that decomposition rate of crop residues can decide their retain value depending on nutrient release rate. This would facilitate in establishing the relationship between qualities of decomposing residue requirements with crop growth of a particular species.
\end{abstract}


Keywords - crop residue, gross residue potential, agricultural ecological potential, decomposition rate constant, plant residue quality index.

\section{Introduction}

An agro-ecosystem is a smaller unit of natural system mainly dedicated to production of food and fibre. It is an intermediate system affected by both biotic and abiotic factors, though by implementing manipulative measures its dynamics could be controlled up to an extent. The variety and range of anthropogenic inputs in synchronisation with favourable geographical conditions can lead to higher outputs. But in order to obtain the desired results, its natural dynamics must be understood well.

Agro ecosystem is an efficiently rich system in terms of its production value and reusabity of agri-waste. Amount of agriculture waste is mainly determined by plant physiology but also governed by agriculture inputs applied and post-harvest management. Plant physiology determines the leftover part of the plant after harvesting whereas agri-input governs the quality of the residue and harvest management decides the actual amount available for utilization. Each crop in the capacity of its unique physiology produces some amount of residue. As much as the quantity of the crop residue is important, its quality governs the process of decomposition in the soil. The crop residue when decomposes, release nutrient elements into the soil based on their chemical composition (Tamilselvi et al., 2015). Fast decomposing residues release nutrients at faster rate while not necessarily improving the soil quality whereas slowly decomposing residues might positively impact the soil in the long run. Therefore it is important to study the plant physiology as well as chemical make-up before zeroing on its potential of reusage and reapplication in the agriculture soil. 
Uttarakhand is a hilly state which is geographically divided into plains and tarai, bhabhar zone, middle Himalayas, and higher Himalayas. It is generally covered with forests and wastelands with reported total land area of 56.72 lakh ha (Sharma, 2016). Only 14\% land is available for cultivation and out of which $89 \%$ is under small and marginal land holders. Small land holdings face the pressure of producing maximum yield within limited fertilizer and other chemical inputs. Due to ecological and economic constraints these farms have immense scope to develop into organic establishments (Meena and Sharma 2015 ). Crop residues and animal farm waste are the major sources of organic application in the fields. In order to apply plant residues into the soil to take out maximum benefits from the same the quality of a crop residue is studied based on $\mathrm{C}: \mathrm{N}$ ratio, lignin, and polyphenol content. The quality index determines the decomposability of the crop residue which is used to predict the efficiency of its application in the soil. But again, keeping in mind the geographical peculiarity of the state, the crop residues which can be decomposed easily under sub-tropical weather conditions has to be distinguished. Therefore the need to study the chemical composition of plants and its decomposition process is warranted. In the present study the focus would be on estimating the quantity of residue from the major cereal crops as well as assessment of their nutritional quality for their reusability in the agricultural system based on their quality index.

\section{Materials and methods}

The present study was conducted in the agriculture farms of Kedarpur village in Dehradun district, (Uttarakhand $30.2672^{\circ} \mathrm{N}, 78.0465^{\circ} \mathrm{E}$ ) in 2016-17. The soil type of the area is sandy loam and its surface layer has the following properties: The soil is classified as alfisol and its surface layer $(0-15 \mathrm{~cm})$ has the following properties: Organic $\mathrm{C}-1.87 \%$; total $\mathrm{N}-0.17 \%$, $\mathrm{pH}-$ 7.49; EC-490 $\mu \mathrm{S} \mathrm{cm}^{-1}, \mathrm{CEC}-10.23 \mathrm{me} 100 \mathrm{gm}^{-1}$ and a sandy loam texture with sand, $54.9 \%$, silt, $15.8 \%$ and clay, $26.3 \%$. 
This study involved initial chemical characterisation of four major crop residues of the plants; wheat, rice, sugarcane and maize, their quantity estimation and quality analysis using plant residue quality index (PRQI).

Field decomposition was studied using $15 \times 15$ nylon mesh bags of $0.2 \mathrm{~mm}$ through litter bag technique. Litter bags from each residue were collected from the field after 7, 14, 21, and 30 days after study of initiation of the experimental set-up. After the collection of litterbags, their contents were air dried and further analysed. Once dry, samples were weighed and mass loss determined as the difference of initial and final weight.

\subsection{Selection of crops}

The plants were selected based on their highest grain productivity and the availability of maximum crop residue in the Dehradun region. Types of residues were straw from rice, wheat and maize and leaves of sugarcane. Their respective RPR (residue production ratio) was used to measure the gross residue potential of the crop.

\subsection{Plant residue quality index (Tian et al. 1995)}

Plant residue quality index was determined on the basis of three factors of the residue quality that is, C: N ratio, lignin and polyphenol contents as described by Tian et al. (1995). The PRQI equation to calculate the quality parameter was further formulated as

$\mathrm{PRQI}=[1 /(\mathrm{a} \mathrm{C} / \mathrm{N}+\mathrm{b}$ Lignin $+\mathrm{c}$ Polyphenol $)] \times 100$

where $\mathrm{a}, \mathrm{b}$ and $\mathrm{c}$ are coefficients of relative contribution of $\mathrm{C} / \mathrm{N}$ ratio, lignin content $(\%)$ and polyphenol content $(\%)$ to plant residue quality. Multiple regression analysis between mean decomposition rate constants of all the four plant residues, $\mathrm{C} / \mathrm{N}$ ratio, and lignin and polyphenol contents are given in Table 3. Using the $\mathrm{F}$ value of the regression analysis in Table 4, the 
coefficient of relative contribution (CRC) of the three factors to the rate of decomposition was calculated as:

$\mathrm{CRC}=\mathrm{F}$ value of given factor/sum of $\mathrm{F}$ values of three factors

Hence, insertion of the CRC values from Table 1 in eq. (1) yields:

PRQI $=[1 /(0.423 \mathrm{C} / \mathrm{N}+0.439$ Lignin+0.138 Polyphenols $)] \times 100$

\subsection{Estimation of crop residue biomass potential}

The estimation of crop residue generated in an agro system is calculated based on three parameters which are: area covered by the crop, yield of the crop and, residue production ratio. Residue production ratio (RPR) is simply residue available for $1 \mathrm{~kg}$ of crop. Based on the mentioned criteria gross residue potential is calculated as follows:

Gross residue potential $(\mathrm{GRP})=$ Crop area $\mathrm{x}$ Crop yield $\mathrm{x}$ RPR

Where crop area and crop yield are the cultivation area (ha) and yield (tonnes $\mathrm{ha}^{-1}$ ) respectively.

\subsection{Agricultural Ecological potential (AEP)}

Various ecological functions are dependent on the retention of crop residues on the field, such as nutrient cycling, moisture control and, soil organic matter. Ecological potential calculates the limitations to residue extraction for agricultural residues to maintain the ecologial functions.

It is calculated as:-

$\mathrm{AEP}($ tonnes $)=\mathrm{GRP}-(250 \mathrm{x}$ crop area $)$

where 250 , is a constant used assuming that globally 250 tons of residues per $\mathrm{km}^{2}$ of cultivated land can reduce soil erosion and thus maintain ecological functions. 


\section{Results and Discussion}

The production of agricultural residues depends on the volume of produce generated, the crops being produced and the yield of these crops ((Daioglou et al., 2016). In this study the crop residue is defined as the above ground straw and leaves. The yield of any crop can affect the residue potential by affecting the residue to product ratio (RPR), defined as the ratio of above ground crop production to the total grain production (Lal, 2005). The collected data from various studies inferred that the RPR varies across different crop types and tends to decrease with increasing yields (Scarlat et al., 2010). It is due to the fact that increased crop yield results in an increase in grain produced which is chiefly the harvestable component of the plant and therefore very limited residue is left after harvesting (Daioglou et al., 2016).

It is estimated that India generates 500 Mt of crop residue annually (NPMCR, 2014). The uses of crop residues depend on the crops grown in the area, cropping intensity and productivity cross the region. As far as the Uttarakhand region is concerned the estimated crop residue generated annually in the area is approximately 2.4 million tonnes out of which 0.78 million tonnes/year residue is burned (Bhuvaneshwari et al., 2019). To estimate the generation of crop residue within the time frame of this study, the data of crop production for 2016-17 in Dehradun was sourced from the official site of the agriculture department of government of Uttarakhand, Table 1. The crop production was segmented in the hilly area and plain area based on the topography of the region. Wheat and rice were grown in the much larger area in comparison to maize and sugarcane. The production rate followed similar trend in cereal crops of wheat>rice>maize, although highest production was observed in sugarcane but keeping in view its higher biomass than the cereal crops, it is kept in the separate food producing plant category. Obviously, plains area of the region have large production area therefore the crop yield was also higher accordingly. Whereas in the case of maize, irrespective of the difference 
in area under cropping system, the crop production as well as crop yield was nearly same in both the plains and hilly areas.

Gross residue potential is calculated to estimate the theoretical availability of residue generated based on the crop produced, area under production and RPR. It is estimated that rice, sugarcane, wheat, and cotton are the major contributor to India's crop residue biomass pool (Hiloidhari et al., 2014). In the selected crops of the present study, highest GRP was calculated in the decreasing order of wheat>maize>rice>sugarcane (Table 2). This observation differs from the data of national trend of GRP. The reason could be attributed to the fact that RPR value differs for different crops. Various factors also affect the length of the residue portion of the harvested crop, yield been the most imperative factor. Crop yield determines the harvestable part of the crop, more the crop yield lesser will be the residual part of the plant. In the present context although maize have comparable yield to rice but it has high RPR value which resulted in increased GRP of maize residue.

Surplus residue potential is calculated after taking into account the other competing uses of the crop residues and it is only available for the bioenergy production (Hiloidhari et al., 2014). In the present study surplus fraction is not studied since the data for the competing uses of residues in not available widely. Furthermore, there could be discrepancy in the data since no recent studies has been done to establish the multiple uses of crop residues state wise. There is limited data available, therefore an agency BRAI which calculated the surplus residue potential level at national level, did so assuming that since 2004 there is no change in the pattern of the competing use of the crop residues (Suresh et al., 2016)

Agricultural ecological potential (AEP) is more concerned with the ecological services which could be provided by the crop residues. AEP is defined as the theoretical potential minus residue requirements to avoid environmental degradation which is equivalent to $250 \mathrm{t} \mathrm{km}^{-2}$ 
(Daioglou et al., 2016). Other than utilizing crop residues for either household or commercial purpose, it is known to provide various ecosystem services which entails maintaining SOC, water retention in the soil, prevention from soil diseases, prevention of biodiversity (BlancoCanqui \& Lal, 2007; Devi et al., 2017).

The quantity of crop residue required to provide these ecosystem services is a tedious task and would require a lots of data collection. The level of details required to be able to come up with a certain quantity is not possible. Therefore, Gallagher et al. (2003) used a constrained value which could be applied globally in order to ensure the retention of crop residue amount in the agricultural fields for environmental protection. The value is assumed on the dependence of soil fertility on SOC. To determine the amount of residue to be required to confer all the ecological services is dependent on multiple factors like soil condition, climatic condition and other field management activities. SOC is a prime factor which is often affected by all the above mentioned biotic and abiotic components of the soil. Though, tillage affects the SOC embedded in the soil, but increased farm techniques can improve residue removal activity without affecting the SOC in the soil (Johnson et al., 2006). To deduct the constrained value, a direct relationship of ecosystem services and soil erosion was established which describes the interdependence such as all the ecosystem services could be maintained if there is no soil erosion when retention of crop residue in the fields (Gallagher et al., 2003; Papers et al., 2014).

The results in Table 2 imply that approximately $48 \%$ of gross agricultural residues of wheat and maize have to remain on the field for ecological services. While, it was found to be less than $30 \%$ in case of rice and sugarcane. The ecological use directly depends on the land area being used and increase accordingly. But, in the case of intensive agriculture having lower land area but higher agricultural output are found to have larger ecological potential. The results explain the ecological importance of retaining crop residues in the agriculture field to maintain 
the overall quality status of the soil of the area (Bhatt et al., 2016). Higher the crop production more should be the amount of crop residues left on the fields.

Applications of plant residues have beneficial effect on the soil nutrients, physicochemical properties, and biological dynamics (Elliott et al., 1978; Hiloidhari et al., 2014; Kotroczó et al., 2014; Purohit et al., 2017). However, the effect of plant residues on affecting the quality of the soil depends on the decomposition pattern and nutrient release rate of the residues. Both slow and fast decomposing plant residues poses different productivity effects on the soil as the fast decomposing residues will provide nutrients at the initial stages of the sowing without affecting the physical properties of the soil, whereas slow decomposed residues will have opposite effect of affecting soil aggregates or moisture retention but nutrient release will be slow in the initial phases of the crop growth (Tian et al. 1995). Decomposition process is affected by the $\mathrm{C} / \mathrm{N}$ ratio, its lignin, and polyphenol contents. The plant quality index given by Tian et al. (1995) integrated the above mentioned parameters to develop a residue quality index, to understand the chemical nature of the residue which influences its decomposition pattern. In the present study the formula is being used to study the appropriation of crop residues for its utility in improving the soil nutritional quality. Table 3 describes the initial chemical properties of the crop residues before its application for decomposition. The results showed that soil $\mathrm{pH}$ for rice and maize is slightly acidic while it is basic for wheat and sugarcane crops. Lowest lignin content was present in the wheat straw which explains its faster decomposability whereas rest the residues having higher lignin content takes time longer than wheat to decompose. Imperatively, $\mathrm{C}$ : $\mathrm{N}$ ratio was found highest in the order of sugarcane $>$ maize $>$ rice $>$ wheat, which implies that residual properties of wheat are the most favourable for fast decomposition. The nearest ratio to $\mathrm{C}: \mathrm{N}$ of $24: 1$ is said to be most conducive for the microbes to work upon the waste of any nature (Lynch et al., 2016). By incorporating the observed values in the formula given in eq (1) the PRQI was calculated for the selected 
crop residues. The resultant PRQI was highest for wheat and rice and lowest for the sugarcane (Table 5). It is proposed that decomposition rate is directly correlated to the quality index of the plant as quality parameters of crop residue decide the decomposition rate constant. It is also proved by the correlation between PRQI and decomposition rate constant of the selected crops showed in the Figure 1.

Mulching plays an important role in defining the microclimate of the region, it is placed on. As it generally covers the top soil of the area, restricting the solar penetration into the soil, thus affects the soil temperature by reduction in the degrees just beneath the mulch. Crop residue decomposition puts a similar conditions when comes in contact of the soil. Temperature of the soil further influences the moisture being negatively correlated to each other. In the present study the effect of PRQI in correlation with both soil temperature and moisture defines the impact of quality parameter of crop residue on the mentioned soil physical parameters. Figure 2 showed that crop residues with lower PRQI does not decompose quickly, remains in the soil for a longer duration thus bringing microclimatic changes in the under soil. Sugarcane having low PRQI is observed to have decreased soil temperature and correspondingly increased moisture content than the highest PRQI wheat straw. Whereas wheat straw decomposed at a faster rate therefore did not influence the soil temperature and moisture as an immediate effect. The decomposition of crop residues progressively declines the soil moisture and temperature (Mary et al., 1996; Quemada \& Cabrera, 1997; Thongjoo et al., 2005). Even though retention of soil moisture is a beneficial aspect of soil quality but in terms of nutrient release faster decomposition rate has superfluous effect of mineralization process than slow decomposing crop residues.

Further effects of PRQI on the microbial load of the soil were studied and the results are represented in the Figure 3. It was observed that crop residues with low PRQI under decomposition was weighed down by higher number of fungal than bacterial colonies. High 
moisture supports the growth of fungi; since sugarcane leaves residue had higher moisture content during initial phases of decomposition therefore it can be attributed to optimum growth conditions for the dwelling of fungal population. On the contrary, slightly less humid conditions with optimum temperature near $37^{0} \mathrm{C}$ led to the propagation of more bacterial growth in the wheat straw residue (Rui et al., 2009). The plant litter decomposition is highly dependent on the $\mathrm{C}$ : $\mathrm{N}$ ratio as it also entails the information about the maturity stage of the residue. Mature plants have more complex compounds in their structural frame and hence require more log phased microflora to decompose the stable compounds (Alexander, 1977). The bacterial to fungal ratio determine the response of microbial community to the availability of mature or young plant litter. As mature plants have more recalcitrant compounds such as lignin content so will be prevailed by fungus growth and younger plant litter is richer in nitrogen content therefore attracts more bacterial community for its decomposition (Astaraei, 2008). In the present study it was more evident that higher bacterial to fungal ratio supports grain crop residues than sugarcane leaves residue. Though, lignin content of sugarcane leaves residue was comparable to other crop residues but due to its low nitrogen content it takes more efforts to decompose than the other crops. But with the aid of PRQI the decomposability of any crop residue could be easily predicted before its application in the agriculture fields for various soil improving mechanisms.

\section{Conclusion}

In the present study the selection of crop residues was done on the basis of their applicability in the agricultural fields for improving the soil quality and draw out ecosystem services. The use of agricultural ecological potential could prove to be an important tool to evaluate the amount of residue required for performing the ecosystem services. Differences between production methods and ecological constraints, restricts the utilization of crop residues for soil coverage. The AEP method should be used to calculate the amount of residue allowed to be 
removed to incorporate into the soil as mulch or compost. The feedback of residue incorporation of distinct residues should further be investigated as how it impacted the other competing uses. Further, the application of different crop residues in the fields could be studied through PRQI dependent on lignin, C/ N, and polyphenol content. The decomposition rate of the crop residues can decide their applications in the soil of standing crops depending on the nutrient release rate in the initial phases of the growth. PRQI can further be utilized to determine the relationship between crop residue decomposition rate and crop growth performance. Research with more plant residue species under a wider range of ecological conditions can be summarised in a data set to establish the relationship between quantities of decomposing residues requirements with crop growth of a particular species.

Funding: This research did not receive any specific grant from funding agencies in the public, commercial, or not-for-profit sectors.

\section{Declaration of interests}

The authors declare that they have no competing interests

\section{References}

Alexander, M. (1977). Introduction to soil microbiology. Introduction to Soil Microbiology., Ed. 2. https://www.cabdirect.org/cabdirect/abstract/19780646767

Astaraei, A. (2008). Microbial count and succession,soil chemical properties as affected by organic debrises decomposition. American-Eurasian Journal of Agricultural \& Environmental Science, 4(2), 178-188. https://www.idosi.org/aejaes/jaes4(2)/8.pdf

Bhatt, R., Kukal, S. S., Busari, M. A., Arora, S., \& Yadav, M. (2016). Sustainability issues on rice-wheat cropping system. In International Soil and Water Conservation Research (Vol. 4, Issue 1, pp. 64-74). Elsevier. https://doi.org/10.1016/j.iswcr.2015.12.001

Bhuvaneshwari, S., Hettiarachchi, H., \& Meegoda, J. N. (2019). Crop residue burning in India: Policy challenges and potential solutions. International Journal of Environmental 
Research and Public Health, 16(5), 832. https://doi.org/10.3390/ijerph16050832

Blanco-Canqui, H., \& Lal, R. (2007). Soil structure and organic carbon relationships following 10 years of wheat straw management in no-till. Soil and Tillage Research, 95(1-2), 240-254. https://doi.org/10.1016/J.STILL.2007.01.004

Daioglou, V., Stehfest, E., Wicke, B., Faaij, A., \& van Vuuren, D. P. (2016). Projections of the availability and cost of residues from agriculture and forestry. GCB Bioenergy, $8(2)$, 456-470. https://doi.org/10.1111/gcbb.12285

Devi, S., Gupta, C., Jat, S. L., \& Parmar, M. S. (2017). Crop residue recycling for economic and environmental sustainability: The case of India. Open Agriculture, 2(1), 486-494. https://doi.org/10.1515/opag-2017-0053

Elliott, L. F., McCalla, T. M., \& Waiss, A. (1978). Phytotoxicity associated with residue management. In W.R. Oschwald (ed) Crop residue management systems. American Society of Agronomy, Madison WI.

Gallagher, P. W., Dikeman, M., Fritz, J., Wailes, E., Gauthier, W., \& Shapouri, H. (2003). Supply and social cost estimates for biomass from crop residues in the United States. Environmental and Resource Economics, 24(4), 335-358. https://doi.org/10.1023/A:1023630823210

Hiloidhari, M., Das, D., \& Baruah, D. C. (2014). Bioenergy potential from crop residue biomass in India. In Renewable and Sustainable Energy Reviews (Vol. 32, pp. 504-512). https://doi.org/10.1016/j.rser.2014.01.025

Johnson, J. M. F., Allmaras, R. R., \& Reicosky, D. C. (2006). Estimating source carbon from crop residues, roots and rhizodeposits using the national grain-yield database. Agronomy Journal, 98(3), 622-636. https://doi.org/10.2134/agronj2005.0179

Kotroczó, Z., Veres, Z., Fekete, I., Krakomperger, Z., Tóth, J. A., Lajtha, K., \& Tóthmérész, B. (2014). Soil enzyme activity in response to long-term organic matter manipulation. Soil Biology and Biochemistry, 70, 237-243. https://doi.org/10.1016/j.soilbio.2013.12.028

Lynch, M. J., Mulvaney, M. J., Hodges, S. C., Thompson, T. L., \& Thomason, W. E. (2016). Decomposition, nitrogen and carbon mineralization from food and cover crop residues 
in the central plateau of Haiti. SpringerPlus, 5(1), 973. https://doi.org/10.1186/s40064016-2651-1

Mary, B., Recous, S., Darwis, D., \& Robin, D. (1996). Interactions between decomposition of plant residues and nitrogen cycling in soil. Plant and Soil, 181(1), 71-82. https://doi.org/10.1007/BF00011294

Meena, V. S., \& Sharma, S. (2015). Organic farming: A case study of Uttarakhand Organic Commodity Board. Journal of Industrial Pollution Control, 31(2), 201-206.

NPMCR. (2014). National Policy for Management of Crop Residues (NPMCR) Incorporation in soil and Mulching Baling/Binder for domestic/industrial as fuel Government of India Ministry of Agriculture Department of Agriculture \&amp; Cooperation (Natural Resource Management. http://agricoop.nic.in/sites/default/files/NPMCR_1.pdf

Papers, A. L., Liska, A. J., Yang, H., Milner, M., Goddard, S., Blanco-Canqui, H., Liska, A. J. ;, Yang, H. ;, Milner, M. ; Goddard, S. ;, Blanco-Canqui, H. ;, Pelton, M. P. ;, Fang, X. X. ;, Zhu, H. ;, \& Suyker, A. E. (2014). Adam Liska Papers. 16. https://doi.org/10.1038/NCLIMATE2187

Purohit, P., Jaiswal, B., Prasad, S., Dwivedi, R., Singh, S., Rani, R., Tons, S., Pepper, B., Millets, S., Flower, S., Potato, S., Article, R., Devi, S., Gupta, C., Jat, S. L., Parmar, M. S., Hazra, K. K., Kumar, N., Singh, U., ... van Vuuren, D. P. (2017). Sustainability Issues On Rice-Wheat Cropping System Sustainability issues on rice - wheat cropping system. Journal of Agricultural Science, 9(December), 108. https://doi.org/10.1016/j.iswcr.2015.12.001

Quemada, M., \& Cabrera, M. L. (1997). Temperature and moisture effects on C and N mineralization from surface applied clover residue. Plant and Soil, 189(1), 127-137. https://doi.org/10.1023/A:1004281804058

Rui, J., Peng, J., \& Lu, Y. (2009). Succession of bacterial populations during plant residue decomposition in rice field soil. Applied and Environmental Microbiology, 75(14), 4879-4886. https://doi.org/10.1128/AEM.00702-09

Sharma, M. (2016). Population Growth and its Impact on Natural Resources: A Study of Uttarakhand State. IOSR Journal Of Humanities And Social Science (IOSR-JHSS, 21(9), 
54-60. https://doi.org/10.9790/0837-2109055460

Suresh, S., Kumar, A., Shukla, A., Singh, R., \& Krishna, C. M. (2016). Biofuels and bioenergy (BICE2016) : International Conference, Bhopal, India, 23-25 February 2016. 327.

https://books.google.co.in/books?id=_63LDgAAQBAJ\&pg=PA78\&lpg=PA78\&dq=Bio mass + Resource + Atlas + of + India $+($ BRAI $) \&$ source $=$ bl\&ots $=6$ QvwlmKDgv\&sig $=$ ACfU3 U1tsIGnnqg7dNc80BIGs_ReZAAMug\&hl=en\&sa=X\&ved=2ahUKEwj9vITovp_gAhU U2o8KHRE8CdoQ6AEwD3oECAkQAQ\#v=onepage\&q=Biomass

Tamilselvi, S. M., Chinnadurai, C., Ilamurugu, K., Arulmozhiselvan, K., \& Balachandar, D. (2015). Effect of long-term nutrient managements on biological and biochemical properties of semi-arid tropical alfisol during maize crop development stages. Ecological Indicators, 48, 76-87. https://doi.org/10.1016/j.ecolind.2014.08.001

Thongjoo, C., Miyagawa, S., \& Kawakubo, N. (2005). Plant Production Science Effects of Soil Moisture and Temperature on Decomposition Rates of Some Waste Materials from Agriculture and Agro-industry. https://doi.org/10.1626/pps.8.475

Tian G, Brussaard L, Kang BT (1995). Applied Soil Ecology An index for assessing the quality of plant residues and evaluating their effects on soil and crop in the (sub-) humid tropics. Applied Soil Ecology 2:25-32

Tian G, Okoh AI, Kolawole GO, Salako FK (2007) Effects of residue quality and climate on plant residue decomposition and nutrient release along the transect from humid forest to Sahel of West Africa Effects of residue quality and climate on plant residue decomposition and nutrient release along the tr. Biogeochemistry 86:217-229. doi: 10.1007/s10533-0079158-3 


\section{Tables}

Table 1. Total area, production, and average yield under rice, wheat, maize, and sugarcane in the year 2016-17

\begin{tabular}{|l|l|l|l|l|}
\hline District & Crop & Area (ha) & Production (Metric ton) & Average yield (ton ha ${ }^{-1}$ ) \\
\hline \multirow{4}{*}{ Rice } & Dehradun (hills) & 1312 & 2865 & 21.84 \\
\cline { 2 - 5 } & Dehradun (plains) & 7872 & 15991 & 20.31 \\
\cline { 2 - 5 } & Dehradun (total) & 9184 & 18856 & 21.00 \\
\hline \multirow{3}{*}{ Wheat } & Dehradun (hills) & 3748 & 7035 & 18.77 \\
\cline { 2 - 5 } & Dehradun (plains) & 12947 & 37745 & 29.15 \\
\cline { 2 - 5 } & Dehradun (total) & 16695 & 44780 & 29.15 \\
\hline \multirow{2}{*}{ Maize } & Dehradun (hills) & 3423 & 7555 & 22.07 \\
\cline { 2 - 5 } & Dehradun (plains) & 3604 & 7954 & 22.07 \\
\cline { 2 - 5 } & Dehradun (total) & 7027 & 15509 & 22.00 \\
\hline \multirow{2}{*}{ Sugarcane } & Dehradun (total) & 3887 & 251878 & 648 \\
\cline { 2 - 5 } & & & & \\
\hline
\end{tabular}

*Source :- Agriculture department, Govt. of Uttarakhand. www.agriculture.uk.gov.in 
Table 2. Available and ecological potential for cereals and sugarcane crop

\begin{tabular}{|l|l|l|l|l|}
\hline Crops & RPR & $\begin{array}{l}\text { GRP } \\
\text { (MT) }\end{array}$ & AEP (MT) & $\begin{array}{l}\text { \% AEP TO } \\
\text { GRP }\end{array}$ \\
\hline Rice Hills & 1.5 & 4727.92 & 1447.92 & 30.62 \\
\hline Rice Plains & 1.5 & 26380.25 & 6700.25 & 25.39 \\
\hline Rice Total & 1.5 & 31822.56 & 8862.56 & 27.84 \\
\hline Wheat Hills & 1.5 & 11607.74 & 2237.74 & 19.27 \\
\hline Wheat Plains & 1.5 & 62271.83 & 29904.33 & 48.02 \\
\hline Wheat Total & 1.5 & 80298.78 & 38561.28 & 48.02 \\
\hline Maize Hills & 2 & 16620.03 & 8062.53 & 48.51 \\
\hline Maize Plains & 2 & 17498.86 & 8488.86 & 48.51 \\
\hline Maize Total & 2 & 34010.68 & 16443.18 & 48.34 \\
\hline Sugarcane Total & 0.05 & 13853.27 & 4135.77 & 29.85 \\
\hline
\end{tabular}

Table 3. Initial residues quality variables

\begin{tabular}{|l|l|l|l|l|}
\hline $\begin{array}{l}\text { Chemical } \\
\text { properties }\end{array}$ & Rice & Wheat & Sugarcane & Corn \\
\hline pH & 5.85 & 6.23 & 6.00 & 5.88 \\
\hline EC ( $\mathrm{SS} / \mathrm{cm})$ & 101.7 & 143 & & \\
\hline $\begin{array}{l}\text { Organic carbon } \\
\text { (g/kg) }\end{array}$ & 223 & 302 & 232 & 348 \\
\hline Total Carbon (\%) & 44 & 51 & 34 & 46 \\
\hline $\begin{array}{l}\text { Total Nitrogen } \\
\text { (\%) }\end{array}$ & 6.7 & 1.47 & 0.12 & 0.95 \\
\hline Dry weight g/m & 339 & 443 & 482 & 421 \\
\hline Lignin \% & 13.98 & 16.2 & 13.25 & 14.5 \\
\hline Cellulose\% & 39.1 & 38.4 & 42.13 & 37.9 \\
\hline Hemicellulose\% & 26.40 & 35.2 & 40.11 & 35.7 \\
\hline Lignin:N & 2.08 & 10.9 & 110.41 & 15 \\
\hline C:N & 6.5 & 34.69 & 283 & 48.42 \\
\hline
\end{tabular}


Table 4. Results of multiple regressions between mean decomposition rate constants of four plant residues and $\mathrm{C} / \mathrm{N}$ ratio, lignin content (\%) and polyphenol content (\%), and the resulting coefficients of relative contribution (CRC) of chemical factors to decomposition

\begin{tabular}{|l|l|l|l|}
\hline Chemical factor & Regression Coefficient & F-value & Coefficient of relative contribution \\
\hline $\mathrm{C} / \mathrm{N}$ & 0.0038 & 16.6 & 0.423 \\
\hline Lignin & 0.0030 & 17.2 & 0.439 \\
\hline Polyphenol & 0.0189 & 5.4 & 0.138 \\
\hline
\end{tabular}

Table 5. Plant residue quality index of the selected crops

\begin{tabular}{|l|l|}
\hline Crop residue & PRQI \\
\hline Wheat & 4.5 \\
\hline Rice & 4.2 \\
\hline Sugarcane & 1.8 \\
\hline Maze & 3.7 \\
\hline
\end{tabular}




\section{FIGURES}

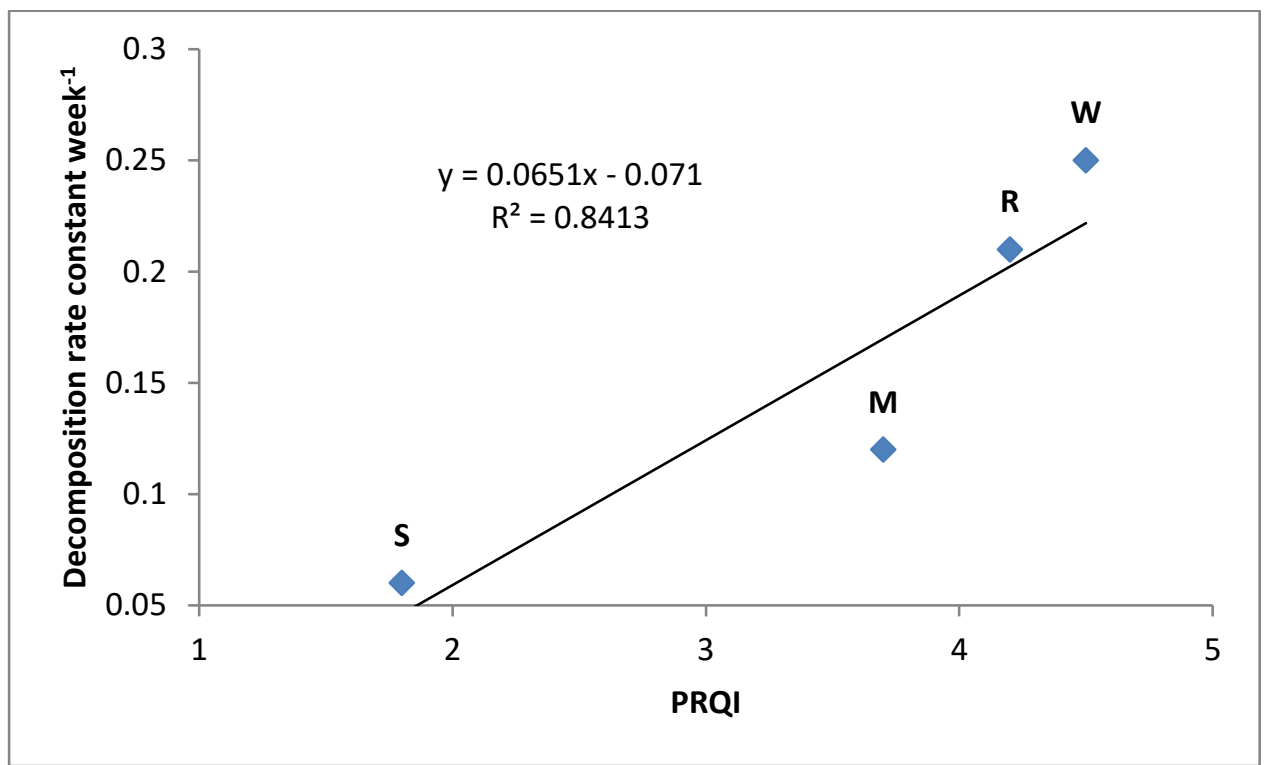

Fig.1 Correlation between PRQI and decomposition rate constant of crop residues in the 2016-17 cropping season. (S-sugarcane leaves residue; M-maize leaves residue; R-rice straw; W-wheat straw) 

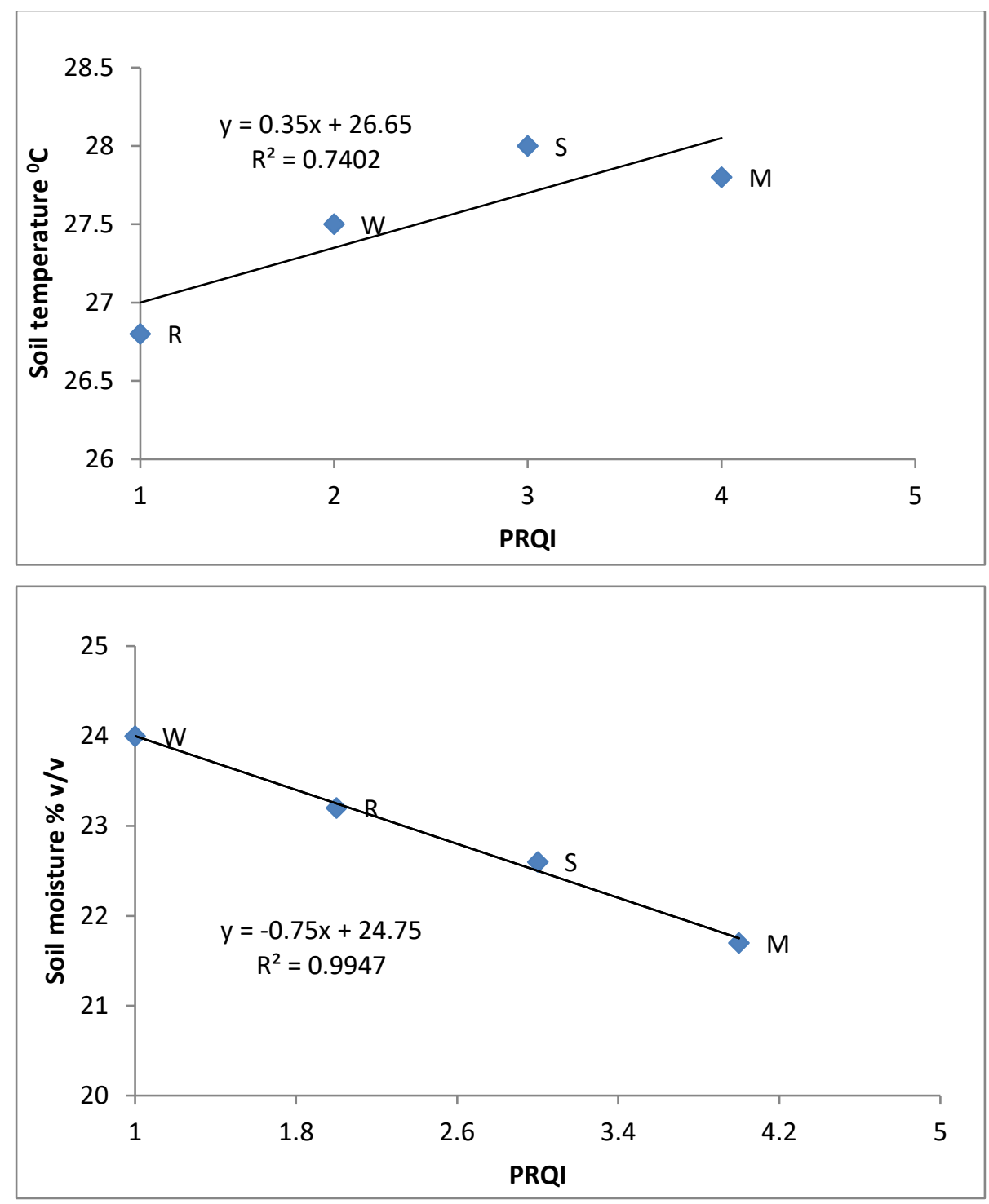

Fig.2. Correlation between PRQI and mean soil temperature $(10 \mathrm{~cm})$ and mean soil moisture content $(0-10 \mathrm{~cm})$ during the decomposition of the crop residues. (S-sugarcane leaves residue; M-maize leaves residue; R-rice straw; $\mathrm{W}$-wheat straw) 

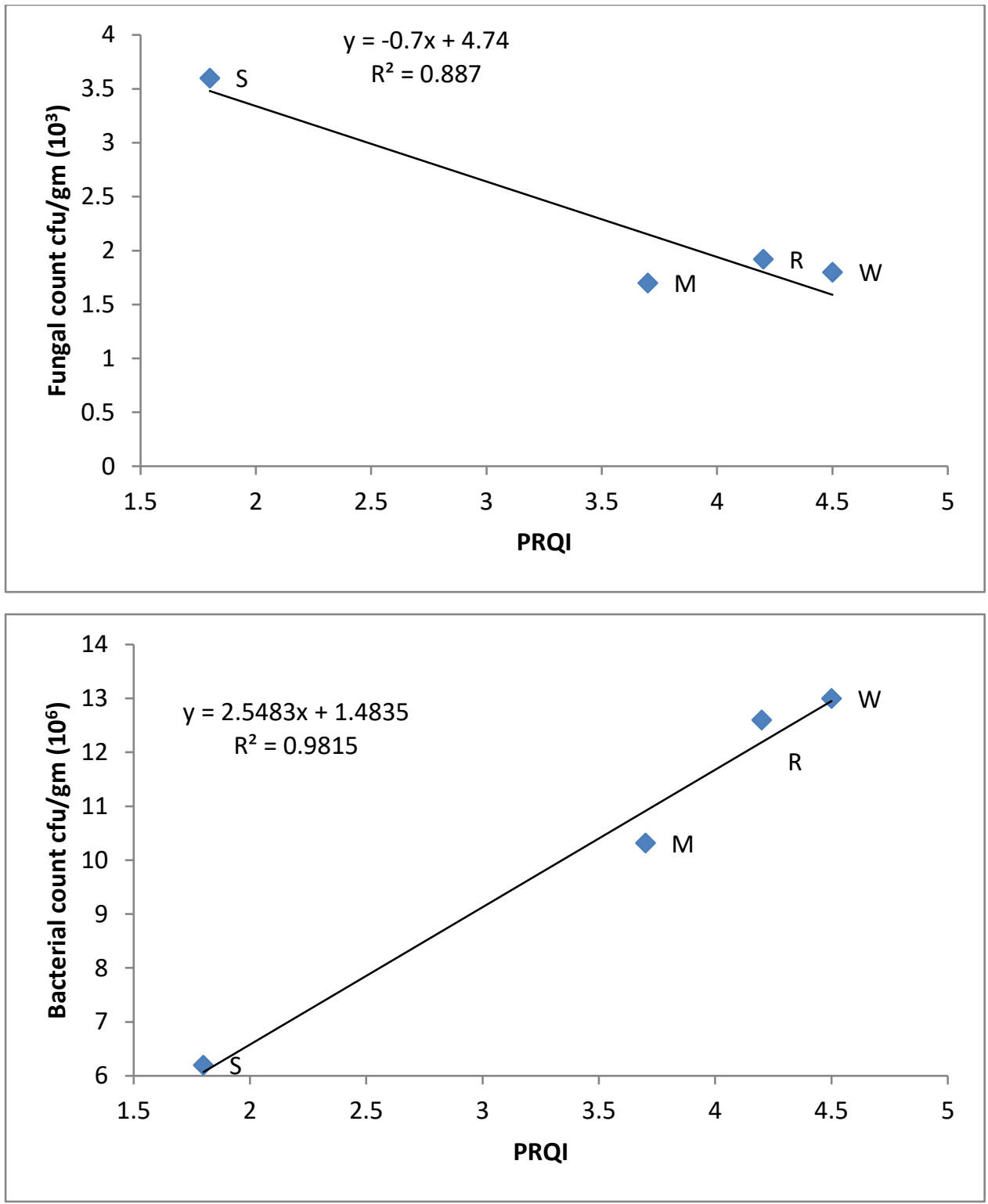

Fig.3. Correlation between the PRQI and fungal count and bacterial count during the decomposition of the crop residues. (S-sugarcane leaves residue; M-maize leaves residue; R-rice straw; W-wheat straw) 